\title{
PELAKSANAAN PUTUSAN HAKIM PENGADILAN TATA USAHA NEGARA TERHADAP SENGKETA PEMBERHENTIAN DIREKTUR TEKNIK PDAM TIRTA
}

\author{
Dimas Kurniawan Figna \\ DimasKurniawan12123@gmail.com \\ 2010003600209 \\ Universitas Ekasakti Padang
}

\section{A. PENDAHULUAN}

Pengadilan Tata Usaha Negara (PTUN) peradilan yang berada dibawah naungan Mahkamh Agung (MA) merupakan salah satu lembaga peradilan di lingkungan Peradilan Tata Usaha Negara yang berkedudukan di ibu kota Provinsi atau kota yang memeriksa, memutus, dan menyelesaikan sengketa Tata Usaha Negara di tingkat pertama.

Sengketa Tata Usaha Negara adalah sengketa yang timbul dalam bidang Tata Usaha Negara antara orang atau badan hukum perdata dengan Badan atau Pejabat Tata Usaha Negara, baik di Pusat maupun di daerah, sebagaimana akibat dikeluarkannya keputusan Tata Usaha Negara, termasuk sengketa kepegawaian berdasarkan peraturan perundang-undangan yang berlaku. Pengadilan Tata Usaha Negara dibentuk melalui Keputusan Presiden dengan daerah hukum meliputi wilayah Kota Provinsi atau Kabupaten.

Dan telah menjadi tugas pokok dan fungsi PENGADILAN TATA USAHA NEGARA (PTUN) untuk memeriksa, memutus, dan menyelesaikan sengketa Tata Usaha Negara di tingkat pertama hingga pelaksanaan eksekusi putusan hakim tata usaha negara. Putusan merupakan pernyataan hasil pertimbangan hakim yang dituangkan dalam bentuk tertulis dan kemudiaan dibacakan oleh hakim diakhir persidangan. Sebagai hasil pertimbangan hakim atas Eksekusi dapat diartikan suatu tindakan lanjut dalam hal melaksanakan putusan pengadilan yang telah mempunyai kekuatan hukum yang tetap (inkracht). Eksekusi putusan pengadilan adalah 
pelaksanaan putusan pengadilan oleh atau dengan bantuan pihak luar dari para pihak. Dalam hukum administrasi negara tentunya eksekusi memiliki prosedur dan sistem yaitu berlandaskan kepada Undang-Undang Nomor 30 Tahun 2014 tentang Administrasi Negara yang sekarang telah diberi wewenang kepada pengadilan tata usaha negara sebagai lembaga yang mengadili sengketa Administrasi Negara dengan berlandaskan pada UU No.5 Tahun 1986 tentang Pengadilan Tata Usaha Negara dan mengatur tentang prosedur administrasi negara. Eksekusi diatur dalam Pasal 82 Undang-Undang Nomor 30 Tahun 2014 tentang administrasi negara, sebagai berikut:

1. Penjatuhan sanksi sebagaimana dimaksud dalam Pasal 81 dilakukan oleh:

a. Atasan pejabat yang menetapkan keputusan;

b. kepala daerah apabila keputusan ditetapkan oleh pejabat daerah;

c. menteri/pimpinan lembaga apabila keputusan ditetapkan oleh pejabat dilingkungannya;

d. Presiden apabila keputusan ditetapkan oleh para menteri / pimpinan lembaga.

2. Penjatuhan sanksi sebagaimana dimaksud dalam pasal 81 dilakukan oleh:

a. gubernur apabila keputusan ditetapkan oleh bupati/ wali kota; dan

b. menteri yang menyelenggarakan urusan pemerintahan dalam negeri apabila keputusan ditetapkan oleh gubernur.

Dalam hukum administrasi negara tentunya eksekusi memiliki prosedur dan sistem yaitu berlandaskan kepada Unadang Undang nomor 30 Tahun 2014 tentang administrasi negara yang sekarang telah diberi wewenang kepada pengadilan tata usaha negara sebagai lembaga yang mengadili sengketa administrasi negara dengan berlandaskan pada UU NO.5 Tahun 1986 tentang pengadilan tata usaha negara dan mengatur tentang prosedur administrasi negara. 
Mekanisme pelaksanaan terhadap putusan pengadilan tata usaha diatur dalam Pasal 116 UndangUndang Nomor 51 Tahun 2019, perubahan ke 3 (tiga) Undang-Undang tentang Pengadilan Tata Usaha.

Adapun bunyi ketentuan Pasal 116 pada perubahan kedua tahun 2009 adalah sebagai berikut:

(1) Salinan putusan pengadilan yang telah memperoleh kekuatan hukum tetap, dikirimkan kepada para pihak dengan surat tercatat oleh panitera pengadilan setempat atas perintah ketua pengadilan yang mengadilinya dalam tingkat pertama selambatlambatnya dalam waktu 14 (empat belas) hari kerja.

(2) Apabila setelah 60 (enam puluh) hari kerja putusan pengadilanm yang telah memperoleh kekuatan hukum tetap sebagaimana dimaksud pada ayat (1) diterima tergugat tidak melaksanakan kewajibannya sebagaimana dimaksud dalam Pasal 97 ayat (9) huruf a, keputusan tata usaha negara yang disengketakan itu tidak mempunyai kekuatan hukum lagi.

(3) Dalam hal tergugat ditetapkan harus melaksanakan kewajiban sebagaimana dimaksud dalam Pasal 97 ayat (9) huruf b dan huruf c, dan kemudian setelah 90 (sembilan puluh) hari kerja ternyata kewajiban tersebut tidak dilaksanakan, maka penggugat mengajukan permohonan kepada ketua pengadilan sebagaimana dimaksud pada ayat (1), agar pengadilan memerintahkan tergugat melaksanakan putusan pengadilan tersebut.

(4) Dalam hal tergugat tidak bersedia melaksanakan putusanpengadilan yang telah memperoleh kekuatan hukum tetap, terhadap pejabat yang bersangkutan dikenakan upaya paksa berupa pembayaran sejumlah uang paksa dan/atau sanksi administratif. 


\section{B. PEMBAHASAN}

Pelaksanaan putusan PTUN (Eksekusi) adalah aturan tentang cara dan syarat-syarat yang dipakai oleh perlengkapan negara guna membantu pihak yang berkepentingan untuk menjalankan putusan hakim apabila pihak yang kalah tidak bersedia mematuhi isi putusan dalam waktu yang ditentukan.

1. Duduk perkara

Pelaksanaan eksekusi putusan hakim Pengadilan Tinggi Tata Usaha Negara (PTTUN) medan Nomor.05/B/2015/PT.TUN-MDN tentang lanjutan banding dari ptusan hakim Pengadilan Tata Usaha Negara Langkat register perkara Nomor: 09/G/2014/PTUN.BNA tentang pemberhentian direktur teknik Perusahaan Daerah Air Minum Tirta Daroy kota Langkat, dari hasil pemeriksaan sengketa tersebut majelis hakim memutuskan memenagkan pihak penggugat dan hasil banding juga menguatkan hasil putusan tingkat pertama Pengadilan Tata Usaha Negara Langkat dengan putusan sebagai berikut :

a. Mengabulkan gugatan penggugat seluruhnya

b. Menyatakan batal dan memerintahkan untuk mencabut Keputusan Walikota Langkat Nomor.307 tentang pemberhentian direktur teknik dan keputusan Nomor 306 tentang penunjukan pelaksana tugas (Plt).

c. Mewajibkan tergugat merehabilitasi dan mengembalikan penggugat pada jabatan semula dengan segala hak dan tanggung jawabnya berdasarkan ketentuan perundang-undangan yang berlaku.

d. Menghukum tergugat untuk membayar biaya dalam perkara ini sejumlah Rp. 211.000.,(Dua ratus sebelas ribu rupiah). memerlukan pelaksanaan. Namun Pasal 116 ayat (2) Undang-undang Nomor 5 Tahun 1986 dan Undang-undang Nomor 9 Tahun 2004 
memberikan penyelesaian secara otomatis, yaitu apabila dalam waktu 4 (empat) bulan setelah putusan berkekuatan hukum tetap dikirimkan kepada pihak tergugat dan tergugat tidak melaksanakan pencabutan Keputusan Tata Usaha Negara (KTUN) yang telah dinyatakan batal tersebut, maka KTUN tersebut tidak mempunyai kekuatan hukum tetap lagi Dan jika tergugat masih tidak mau melaksanakannya (berdasarkan Pasal 116 ayat (4) Undang-undang Nomor 5 Tahun1986), Ketua Pengadilan mengajukan hal ini kepada instansi atasannya menurut jenjang jabatan. Instansi atasan dalam waktu 2 (dua) bulan setelah menerima pemberitahuan dari Ketua Pengadilan harus sudah memerintahkan pejabat tergugat melaksanakan putusan pengadilan tersebut (lihat Pasal 116 ayat (5) Undang-undang Nomor 5 Tahun 1986). Dalam hal instansi atasan dimaksud tidak mengindahkannya maka Ketua Pengadilan mengajukan hal ini kepada Presiden sebagai pemegang kekuasaan pemerintah tertinggi untuk memerintahkan pejabat yang bersangkutan melaksanakan putusan Pengadilan (lihat Pasal 116 ayat (6) Undang-undang Nomor 5 Tahun 1986).

Unsur eksekusi hierarkis kembali muncul dalam Undang-undangNomor 51 Tahun 2009, pada Pasal 116 ayat (6). Ketua Pengadilan diharuskan untuk mengajukan hal ketidak taatan pejabat tergugat atau termohon eksekusi kepada Presiden sebagai pemegang kekuasaan pemerintah tertinggi untuk memerintahkan pejabat tersebut melaksanakan putusan pengadilan. Di samping itu juga Akan tetapi pelaksanaan putusan diatas tersebut belum terlaksana sebagaimana semestinya mulai dari dikeluarkannya putusan pada tanggal 4 November 2014 hingga sekarang tanggal 18 Februari 2020.

Berdasarkan perintah Ketua Pengadilan yang mengadilinya dalam tingkat pertama salinan putusan pegadilan yang telah memperoleh kekuatan hukum tetap, dikirimkan kepada para pihak dengan surat tercatat oleh Penitera Pengadilan setempat selambat-lambatnya dalam 
waktu 14 (empat belas) hari setelah putusan berkekuatan hukum tetap. Dalam Undang-undang Nomor 51 Tahun 2009 ayat (1) ketentuan waktu 14 (empat belas) hari diubah menjadi 14 (empat belas) hari kerja. Putusan yang mewajibkan kepada pejabat atau badan pemerintah untuk mencabut Keputusan Tata Usaha Negara (KTUN) pada dasarnya mengajukannya kepada lembaga perwakilan rakyat untuk menjalankan fungsi pengawasan. Awal sengketa ini ketika pihak penggugat mengajukan gugatannya yang diterima dan didaftarkan di Kepaniteraan Pengadilan Tata Usaha Negara Langkat pada tanggal 18 juli 2014 dalam register perkara Nomor: 09/G/2014/PTUN.BNA, dan telah dilakukan perbaikan formal pada tanggal 18 Agustus 2014. Adapun yang menjadi objek sengketa adalah keputusan Wali kota Langkat Nomor: 307 Tahun 2014 tentang pemberhentian direktur teknik pada perusahaan daerah air minum (PDAM) Tirta Daroy Langkat, tertanggal pada 28 April 2014/ 28 Jumadil Akhir $1435 \mathrm{H}$ yang berinisial Ir. JZ yang ditanda tangani oleh wakil Wali Kota Langkat.

Dan keputusan Wali Kota Langkat Nomor: 306 Tahun 2014 tentang penunjukan pelaksana tugas (Plt) Direktur teknik pada perusahaan Daerah Air Minum (PDAM) Tirta Daroy Kota Langkat, tertanggal 28 April 2014/ 28 Jumadil akhir 1435 H yang berinisial Ir.MK yang ditandatangani oleh wakil Wali Kota Langkat. Kedua objek sengketa tersebut terbit pada tanggal 28 April 2014,sedangkan gugatan diajukan dan didaftarkan pada tanggal 18 Juli 2014 dengan demikian gugatan masih dalam tenggang waktu 90 (sembilan puluh) hari sebagaimana yang diatur dalam pasal 55 UU No.5 Tahun 1986 tentang Peradilan Tata Usaha Negara. Adapun obyek sengketa sesuai Pasal 1 huruf c UU Nomor 5Tahun 1986 yaitu penetapan tertulis berupa keputusan tata usaha negara yang bersifat konkrit, individual dan final serta menimbulkan akibat hukum bagi seseorang atau badan hukum perdata. Perluasan makna keputusan tata usaha negara sesuai Pasal 87 UU Nomor 30 Tahun 2014 adalah : 
a. penetapan tertulis yang juga mencakup perbuatan faktual

b. Keputusan Badan dan / atau Pejabat di lingkungan eksekutif, legislatif, yudikatif dan penyelenggara negara lainnya.

c. berdasarkan ketentuan perundang undangan dan AAUPB

d. bersifat final dalam arti lebih luas

e. Keputusan yang berpotensi menimbulkanakibat hukum dan/atau

f. Keputusan yang berlaku bagi Warga Masyarakat.

Berdasar ketentuan tersebut di atas, maka yang termasuk keputusan tata usaha negara selain sebagaimana yang telah ditegaskan dalam Pasal 1 huruf c UU Nomor 5 Tahun 1986 tentang Peradilan Tata Usaha Negara, maka termasuk pula keputusan tata usaha negara berdasarkan Pasal 87 UU Nomor 31 Tahun 2014 tentang Administrasi Pemerintahan. Jadi berdasarkan ketentuan dalam kedua pasal dengan dasar hukum perundang-undangan yang berbeda, makna keputusan tata usaha negara menjadi luas. Secara umum ada tiga macam perbuatan pemerintah, yaitu : perbuatan pemerintah dalam bidang pembuatan peraturan perundangundangan (regeling), perbuatan pemerintah dalam bidang keperdataan (materieledaad), perbuatan pemerintah dalam penerbitan ketetapan (beschikking).

\section{PENUTUP}

Berdasarkan beberapa pemaparan sebelumnya, maka dapat pula ditarik kesimpulan sebagai berikut: 
1. Pelaksanaan eksekusi Pengadilan Tata Usaha Negara telah diatur dalam regulasi eksekusi PTUN, namun pada pelaksanaan eksekusi tersebut memiliki kendala karena pada regulasi tersebut belum memiliki daya paksa untuk melaksanakan putusan hakim karena sanksi pada eksekusi putusan Pengadilan Tata Usaha Negara hanya memiliki sanksi administratif dan pada pelaksanaannya dilakukan oleh tergugat sendiri selaku pejabat negara yang hanya berdasarkan pada kesadaran diri seorang pejabat negara dengan iktikad baik untuk melakukan eksekusi putusaan hakim yang telah incraht tersebut. Eksekusi putusan hakim Pengadilan Tata Usaha Negara Langkat pada perkara Nomor.05/B/2015/PT.TUN-MDN tentang pemberhentian direktur teknik pada Perusahaan Daerah Air Minum Tirta Daroy Langkat yang berinisialkan JZ sebagai penggugat dalam perkara ini dari putusan tersebut sama sekali belum terlaksana hingga sekarang tanggal 20 Februari 2020.

2. Penyebab tidak terlaksanaya eksekusi putusan hakim pada perkara ini terbagi menjadi 3 (tiga) sebab yaitu :

a. Sebab dari penggugat sendiri tidak menempuh jalur hokum dalam pelaksanaan putusan hakim selama ini, tidak lagi memproses eksekusi putusan tersebut karena penggugat sendiri ingin menyelesaikan eksekusi pada putusan ini secara internal dengan cara pendekatan kepada SEKDA pemerintah kota Langkat, akan tetapi penggugat terlalaikan akibat kesibukannya melakukan tugas di PDAM Aceh Tamiang sehingga eksekusi belum terlaksana.

b. Sebab dari Pengadilan Tata Usaha Negara (PTUN) Pengadilan Tata Usaha Negara bersifat pasif (Tidak Aktif) dalam melaksankan eksekusi putusan PTUN, dan regulasi pelaksanaan eksekusi masih lemah dan tidak memiliki daya paksa ysng kuat demi terlaksanya eksekusi putusan hakim PTUN. 
c. Sebab dari pihak tergugat (Walikota) Upaya eksekusi putusan pada PTUN lebih bersifat kepada kesadaran diri dan iktikad baik dari pejabat negara yang menjadi tergugat, selaku pihak yang melakukan eksekusi putusan tersebut. Bila pejabat tersebut beriktikad maka pasti akan spontan mengembalikan penggugat ke jabatan semula dan begitu pula sebaliknya.

\section{DAFTAR PUSTAKA}

Darmini Roza dan Laurensius Arliman S, Peran Pemerintah Daerah Di Dalam Melindungi Hak Anak Di Indonesia, Masalah-Masalah Hukum, Volume 47, Nomor 1, 2018. https://doi.org/10.14710/mmh.47.1.2018.10-21

Laurensius Arliman S, Peranan Metodologi Penelitian Hukum di Dalam Perkembangan Ilmu Hukum di Indonesia, Soumatera Law Review, Volume 1, Nomor 1, 201. http://doi.org/10.22216/soumlaw.v1i1.3346.

Laurensius Arliman S, Peran Badan Permusyawaratan Desa di Dalam Pembangunan Desa dan Pengawasan Keuangan Desa, Padjadjaran Journal of Law, Volume 4, Nomor 3, 2017. https://doi.org/10.15408/jch.v4i2.3433.

Laurensius Arliman S, Penanaman Modal Asing Di Sumatera Barat Berdasarkan UndangUndang Nomor 25 Tahun 2007 Tentang Penanaman Modal, Supremasi Hukum, Volume 1, Nomor 1, 2018. http://dx.doi.org/10.36441/hukum.v1i01.102.

Laurensius Arliman S, Memperkuat Kearifan Lokal Untuk Menangkal Intoleransi Umat Beragama Di Indonesia, Ensiklopedia of Journal, Volume 1, Nomor 1, 2018, https://doi.org/10.33559/eoj.v1i1.18.

Laurensius Arliman S, Perkawinan Antar Negara Di Indonesia Berdasarkan Hukum Perdata Internasional, Kertha Patrika, Volume 39, Nomor 3, 2017 , https://doi.org/10.24843/KP.2017.v39.i03.p03.

Laurensius Arliman S, Partisipasi Masyarakat Di Dalam Pengelolaan Uang Desa PascaUndangUndang Nomor 6 Tahun 2014 Tentang Desa, Jurnal Arena Hukum, Volume 12, Nomor 2, 2019, https://doi.org/10.21776/ub.arenahukum.2019.01202.5.

Laurensius Arliman S, Mewujudkan Penegakan Hukum Yang Baik Di Negara Hukum Indonesia, Dialogica Jurnalica, Volume 11, Nomor 1, 2019, https://doi.org/10.28932/di.v11i1.1831.

Laurensius Arliman S, Mediasi Melalui Pendekatan Mufakat Sebagai Lembaga Alternatif Penyelesaian Sengketa Untuk Mendukung Pembangunan Ekonomi Nasional, UIR Law Review, Volume 2, Nomor 2, 2018, https://doi.org/10.25299/uirlrev.2018.vol2(02).1587

Laurensius Arliman S, Peranan Filsafat Hukum Dalam Perlindungan Hak Anak Yang Berkelanjutan Sebagai Bagian Dari Hak Asasi Manusia, Doctrinal, Volume 1, Nomor 2,2016.

Laurensius Arliman S, Ni Putu Eka Dewi, Protection of Children and Women's Rights in Indonesiathrough International Regulation Ratification, Journal of Innovation, Creativity and Change Volume 15, Nomor 6, 2021. 
Laurensius Arliman S, Gagalnya Perlindungan Anak Sebagai Salah Satu Bagian Dari Hak Asasi Manusia Oleh Orang Tua Ditinjau Dari Mazhab Utilitarianisme, Jurnal Yuridis, Volume 3, Nomor 2, 2016, http://dx.doi.org/10.35586/.v3i2.180.

Laurensius Arliman S, Tantangan Pendidikan Kewarganegaraan Pada Revolusi 4.0, Jurnal Ensiklopedia Sosial Review, Volume 2, Nomor 3, $2020 .$. 